\title{
Identification and quantification of pesticide residues in water samples of Dhamrai Upazila, Bangladesh
}

\author{
M. Hasanuzzaman ${ }^{1}$ M. A. $\operatorname{Rahman}^{2} \cdot$ M. A. Salam ${ }^{2}$
}

Received: 12 August 2015/Accepted: 7 October 2016/Published online: 26 October 2016

(C) The Author(s) 2016. This article is published with open access at Springerlink.com

\begin{abstract}
Being agricultural country, different types of pesticides are widely used in Bangladesh to prevent the crop losses due to pest attack which are ultimately drain to the water bodies. The present study was conducted to identify and quantify the organochlorine (DDT, DDE and DDD), organophosphorus (malathion, diazinon and chloropyrifos) and carbamate (carbaryl) residues in water samples of different sources from Dhamrai upazila of Bangladesh using high performance liquid chromatography (HPLC) equipped with ultra violate (UV) detector. Thirty water samples from fish pond, cultivated land and tubewell were collected in winter season to analyze the pesticide residues. Among the organophosphorus pesticides, malathion was present in seven water samples ranging from 42.58 to $922.8 \mu \mathrm{g} / \mathrm{L}$, whereas diazinon was detected in water sample- 8 (WS-8) and the concentration was $31.5 \mu \mathrm{g} / \mathrm{L}$. None of the tested water samples was found to be contaminated with chlorpyrifos, carbaryl or DDT and its metabolites (DDE and DDD). Except for a tube-well water sample, concentrations of the detected residues are above the acceptable limit for human body as assigned by different organizations. To avoid the possible health hazards, the indiscriminate application of pesticides should be restricted and various substitute products like bio-pesticide should be introduced in a broad scale as soon as possible.
\end{abstract}

M. Hasanuzzaman

mhasanuzzaman72@yahoo.com

1 Agrochemical and Environmental Research Division, Institute of Food and Radiation Biology (IFRB), Atomic Energy Research Establishment (AERE), Bangladesh Atomic Energy Commission, Ganakbari, Savar, GPO Box-3787, Dhaka 1000, Bangladesh

2 Department of Zoology, Jahangirnagar University, Savar, Dhaka 1342, Bangladesh
Keywords Pesticide - Water sample - HPLC . Organochlorine $\cdot$ Organophosphorus $\cdot$ Carbamate

\section{Introduction}

Bangladesh is a populous country. It has a population of about 152.25 million as of July 2012 based on population census (BBS 2014). But the provisional estimated population is 157.90 million with growth rate of $1.36 \%$ in Fiscal Year (FY) 2014-15 (MoF 2015). The density of population was 843 per $\mathrm{km}^{2}$ in 2001 which increased to 964 per $\mathrm{km}^{2}$ in 2011 (BBS 2013). More than 75\% of the population lives in rural areas (BBS 2014). The main occupation of this people is agriculture. According to Chowdhury et al. (2011), 80\% of the people depend on agriculture for their livelihood. Agriculture contributes about $18.70 \%$ of the total GDP of Bangladesh (BBS 2013). The GDP in agriculture is 3.04 in FY 2014-15 with great contribution $(22.60 \%)$ in total agricultural income by Fisheries alone (MoF 2015).

According to World Resources Institute (2003), about $57.90 \%$ or a total of 3.40 million hectares out of total land area of Bangladesh is cultivable. According to ADB (2004), agriculture is the single largest contributor to income in Bangladesh and provided jobs for about 36 million out of the 58 million people employed in 2000 . In Bangladesh, about $40 \%$ of the crop loss is caused by pests and insects attack which is a considerable loss (Bagchi et al. 2009). Worldwide, there is an estimation of 70,000 different pest species including insects and mites, plant pathogens and weeds causing an estimated 14, 13 and $13 \%$ agricultural crop damage, respectively (Pimentel 2009a). For providing food security to the increasing 
population, different types of actions have been taken like introduction of high yielding variety but they are very much vulnerable to pests and, as a result, different types of pesticides have been introduced in paddy and crop fields. Using pesticides, crop loss from pests can be reduced to 35-42\% (Pimentel 1997) although risks of using pesticides are serious as well (Pimentel 2009b). For higher production of vegetables, pesticides are being used frequently in Bangladesh (Hossain et al. 2015). Farmers spray excessive amount of organophosphate and carbamate pesticides in the cultivated lands due to inadequate knowledge and instruction about the application of pesticide (Bhattacharjee et al. 2012). Pesticides are toxic material which acts not only on insect and other pests, but also against spread of diseases like malaria, typhoid, plague or sleeping sickness (Islam et al. 2007).

The United Nation has declared 2005-2015 as the "Water for Life" decade (WHO/NHMRC 2006). For the indiscriminate use of pesticide, the surface and ground water bodies are easily being contaminated by runoff water or by rain. The widespread use of pesticides may contaminate the environment and freshwater fish (Rahman 2000). It is unavoidable of entering the fractions of applied insecticides into the aquatic ecosystems because of the application techniques for crop protection (Van Wijngaarden et al. 2005). Due to normal agricultural usage like spray drift, runoff, and leaching, pesticide residues enter into the adjacent water bodies (Van de Zande et al. 2000).

From water bodies, pesticide residues directly or indirectly pass through the food chain and ultimately cause harm to human and other aquatic or terrestrial organisms. The exposure of pesticides to human may cause severe problems. Recio et al. (2001) concluded that organophosphorous pesticides (OP) may affect sperm chromosome segregation and augment the risk for genetic syndromes. Exposure to pesticide residues in the environment is associated with breast cancer risk under specific situations (O'Leary et al. 2004). According to Saldana et al. (2009), exposure to pesticides during pregnancy may increase the risk of hypertensive disorders. Almost $10 \%$ of the total cancer patients are found to be caused due to pesticide poisoning alone ( $\mathrm{Gu}$ and Tian 2005). It was observed by Chen et al. (2004) that the incidence of breast cancer was linearly correlated with the frequency of pesticide uses and organochlorine pesticide DDT and its derivative DDE is possibly responsible for breast cancer.

In 1955, persistent organic pollutants (POPs) were first used in Bangladesh and endrin was the first imported pesticide, of which 3 metric tons (MTs) were imported for agricultural pest control (Badruddin 2004; Rahman 2004). The government provided a $100 \%$ subsidy of pesticides until 1974 and were supplied free of cost to the farmers (Badruddin 2004). The subsidy was reduced to $50 \%$ from
April 1974 to April 1975 when the Department of Agricultural Extension (DAE) sold pesticides of various types at a $50 \%$ subsidy. The pesticides industry was privatized in 1979 when $100 \%$ price was imposed (GoB, MoEF 2005).

At present, there are a total of 141 active ingredients of which 48 active ingredients are registered as public health pesticides (PHP) represented by 122 trade names and 93 active ingredients registered as agricultural pesticides (AP) represented by 303 trade names (GoB, MoEF 2005). Out of the total pesticides use, over 80 pesticides are used in the rice fields (Ara et al. 2014). In Bangladesh from the year 1998 to 2012, the consumption of pesticides increased from 11610.66 to 40882.94 metric tons (MT) comprising insecticides, fungicides, herbicide, rodenticides and public hygiene (BBS 2013).

Like other parts of the country, pesticides are being used legally or illegally in considerable quantities in Dhamrai upazila for various purposes which can easily contaminate the drinking water sources. Sources of drinking water in Dhamrai upazila include tube-well $97.14 \%$, pond water $0.08 \%$, tap water $1.29 \%$ and others $1.49 \%$ (Banglapedia 2015). As a result, these drinking water sources are at high risk of contamination. But information is not available about the level of pesticide residues in different water samples (fish pond, cultivated land and tube-well) of Dhamrai upazila. Moreover, there are no substantial works that have yet been done for the determination of pesticide residue levels in different types of water samples of Dhamrai upazila.

Therefore, Dhamrai upazila has been undertaken as the study area to identify and quantify the suspected pesticide residues in the water samples to demonstrate the present status of pesticides used in that area as well as to compare the present result with the result obtained from the past in home and abroad. This research result will help to know whether the pesticide residues in these water bodies are within the acceptable limit or not and will make the people aware to conserve the good quality of environment. The present study will also help to propose a sound recommendation for minimizing the pesticide pollution in the aquatic environment and will help the researchers as basement data to do further study in this area.

\section{Materials and methods}

The present study was conducted for monitoring pesticide residues in three different sources of pond water, cultivated land water and tube-well water of 10 unions from Dhamrai upaqzila of Dhaka district, Bangladesh (Fig. 1). Water samples were processed for subsequent experiments and for necessary analysis. This analysis was conducted with HPLC method according to Matin et al. (1998). 
Fig. 1 Map of Dhamrai upazila indicating the locations of sample collection

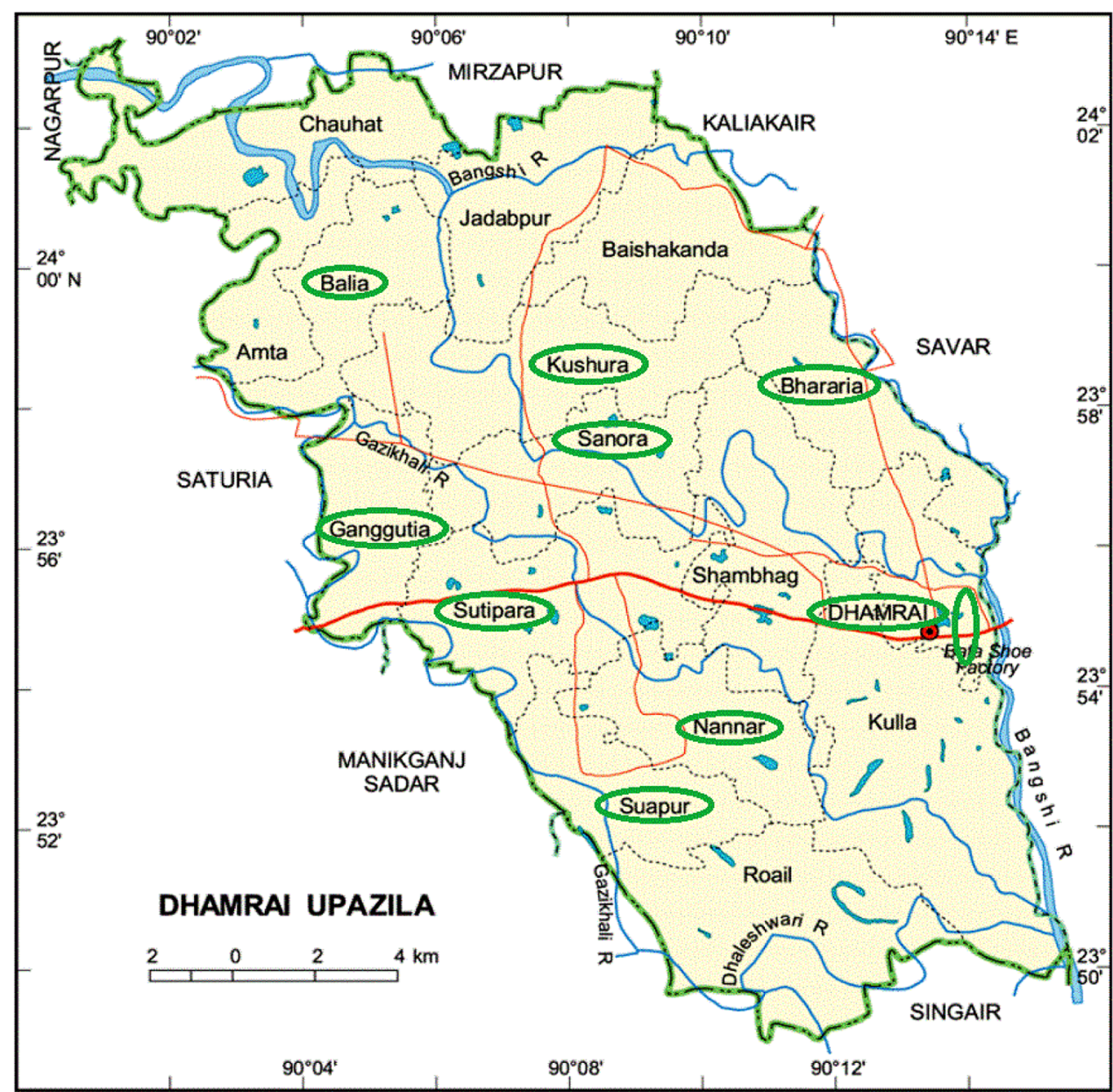

\section{Classification of the suspected pesticides}

The classification of pesticides by hazard is based principally on the acute oral and dermal toxicity to the rat which is a customary procedure in toxicology. Pesticides have been classified on the basis of physical state of the technical product. The GHS (2009) Acute toxicity hazard categories for each pesticide are now presented alongside the existing information. According to WHO (2010) and GHS (2009), the classification of the suspected active pesticides is given in Table 1.

\section{Collection and processing of the water samples}

To undertake the present study, a $1000 \mathrm{~mL}$ for each water sample was collected randomly in glass bottle from three selected sources of ten different unions under Dhamrai upazila. The water samples were labeled and immediately carried to the laboratory of Agrochemical and Environment Research Division (AERD), Institute of Food and Radiation Biology (IFRB), Atomic Energy Research Establishment (AERE), Savar, Dhaka using ice box and kept at
$-20{ }^{\circ} \mathrm{C}$ for further analysis. For determination of pesticide residues, $250 \mathrm{~mL}$ of water sample and $100 \mathrm{~mL}$ double distilled-hexane (DD-hexane) as solvent were taken into a separating funnel and shaken by mixing well for about $10 \mathrm{~min}$ and then kept standing for $10 \mathrm{~min}$ for settling down. Then, lower aqueous layer and upper hexane layer were collected in separate conical flasks. The aqueous layer was re-extracted for two times by adding $50 \mathrm{~mL}$ solvent (DD-hexane) for each re-extraction and then the solvent layer (upper) was collected. Combined extract was collected with $\mathrm{Na}_{2} \mathrm{SO}_{4}$ (anhydrous) for removing water (if any). The collected extract was then concentrated using a rotary vacuum evaporator, and transfer the extract into a cleaned and rinsed vial by rinsing with DD hexane for three times and making the volume $7 \mathrm{~mL}$. In case of color formation, clean-up of the extract was done over florisil and eluted with $2 \%$ diethyl ether n-hexane. Again, the extract was evaporated at $40{ }^{\circ} \mathrm{C}$ by vacuum rotary and transfer into vials. The extracts were then evaporated by nitrogen gas and dried completely. Final volume was made adding $1 \mathrm{~mL}$ of acetonitrile prior to injection into HPLC for pesticide detection. 
Table 1 Classification of the suspected active pesticides ingredients Source: WHO (2010) and GHS (2009)

\begin{tabular}{|c|c|c|c|c|c|c|}
\hline Common name & Class & Chemical type & Physical state & Main use & GHS category & $\begin{array}{l}\mathrm{LD}_{50} \mathrm{mg} / \mathrm{kg} \\
\text { (oral rout) }\end{array}$ \\
\hline Carbaryl [ISO] & II (MH) & $\mathrm{C}$ & S & I & 3 & c300 \\
\hline Chlorpyrifos [ISO] & II (MH) & $\mathrm{OP}$ & $S$ & I & 3 & 135 \\
\hline DDT [ISO] & II (MH) & $\mathrm{OC}$ & $\mathrm{S}$ & I & 3 & 113 \\
\hline Diazinon [ISO] & II (MH) & $\mathrm{OP}$ & $\mathrm{L}$ & I & 4 & 1000 \\
\hline Malathion [ISO] & III (SH) & OP & $\mathrm{L}$ & I & 5 & c2100 \\
\hline
\end{tabular}

"C" preceding the value indicates that it is a value within a wider than usual range, adopted for classification purposes and the $\mathrm{LD}_{50}$ value is a statistical estimate of the number of $\mathrm{mg}$ of toxicant per $\mathrm{kg}$ of bodyweight required to kill $50 \%$ of a large population of test animals

ISO International organization for standardization, $M H$ moderately hazardous, $S H$ slightly hazardous, GHS globally harmonized system, $C$ Carbamate, $O C$ organochlorine compound, $O P$ organophosphorus compound, $I$ insecticide, $S$ solids and $L$ liquid including solids with a melting point below $50{ }^{\circ} \mathrm{C}$

\section{Analysis of the pesticide residues}

For pesticides residue analysis, aliquot $(20 \mu \mathrm{l})$ was injected by microliter syringe into the high performance liquid chromatography (HPLC) fitted with ultra violet (UV) detector. The mobile phase was acetonitrile (65\%). Column $\mathrm{C}_{18}$ (Nova Pack) along with the output device at $254 \mathrm{~nm}$ absorbance was used for determination of the level of organophosphorus, organochlorine and carbamate pesticide residues. Identification and quantification of the suspected pesticide residues were done in relation to retention time (RT) of pure analytical standard and formation of calibration curve from standard samples of different concentrations, respectively. Statistical analysis was performed using SPSS (Version 11.5), a computer-based program for Windows.

The residue " $R$ " can be calculated from the following equation (DFG 1987)

$R=F_{A} \cdot V_{\mathrm{Ex}} \cdot W_{\mathrm{St}} / F_{\mathrm{St}} \cdot V_{i} \cdot G$

where $G$ is the sample volume $(\mathrm{ml}), V_{\mathrm{Ex}}$ is the volume of extract solution (in $\mathrm{ml}$ ), $V_{i}$ is the portion of volume $V_{\mathrm{Ex}}$, injected into the HPLC/volume of sample loop (in $\mu \mathrm{l}$ ), $W_{\mathrm{St}}$ is the amount of pesticide injected with standard solution (ng), $F_{A}$ is the peak area obtained from $V_{\mathrm{i}}\left(\mathrm{mm}^{2}\right)$ and $F_{\mathrm{St}}$ is the peak area obtained from $W_{\mathrm{St}}\left(\mathrm{mm}^{2}\right)$.

\section{Calibration curve for linearity range}

To evaluate linearity of the method, $0.1,1,10,100$ and $1000 \mu \mathrm{g} / \mathrm{L}$ of malathion, diazinon, chlorpyrifos, carbaryl, DDT, DDE and DDD were analyzed by HPLC-UV and the responses were recorded. A plot of the peak areas of the pesticides versus concentrations was found to be linear in the range of $1-1000 \mu \mathrm{g} / \mathrm{L}$ for all pesticides with correlation coefficient $\left(R^{2}\right)$ greater than $0.91(0.96,0.94,0.98,0.91$, $0.95,0.96$ and 0.98 , respectively) and, hence, calibration curves were prepared. This result indicates that these pesticides can be determined at a wide concentration range.

\section{Recovery test}

Percentage recovery of the pesticides was studied by spiking each pesticide in distilled water that contains no pesticides at two concentration levels $(250$ and $500 \mu \mathrm{g} / \mathrm{L})$. Then, the spiked samples were extracted using the same procedure followed in the extraction of other water samples and analyzed using the same method. The mean percentage recoveries for the various pesticides were calculated using the following equation:

$P_{i}=\left(S_{i} / T_{i}\right) \times 100$

where $P_{i}$ is the percent recovery, $S_{i}$ is the analytical results from the laboratory control standard and $T_{i}$ is the known concentration of the spike.

Recovery test has been done twice for each pesticide and the mean value of recovery test as well as the standard deviation $( \pm \mathrm{SD})$ of the results for each pesticide has been calculated and shown in Table 2. The mean percentage recoveries of all tested pesticides were more than $86.32 \%$ which was satisfactory (Table 2).

\section{Limit of detection (LOD) and limit of quantification (LOQ)}

Limit of detection (LOD) and limit of quantification (LOQ) of the pesticides were calculated by preparing different solutions. The solutions were injected and the signal to noise ratio $(\mathrm{S} / \mathrm{N})$ was recorded. The LOD and LOQ were selected as the concentrations of pesticides that give an $\mathrm{S} / \mathrm{N}$ ratio of 3:1 and 9:1, respectively. The LOD and LOQ of the pesticides were 0.3 and $1 \mu \mathrm{g} / \mathrm{L}$, respectively.

\section{Results and discussion}

A number of thirty water samples from Dhamrai upazila were analyzed to detect the organochlorine, organophosphorus and carbamate pesticides using high performance 
Table 2 Results of recovery experiment

\begin{tabular}{llllll}
\hline Pesticide & $\begin{array}{l}\text { Fortification } \\
\text { level }(\mu \mathrm{g} / \mathrm{L})\end{array}$ & \multicolumn{2}{l}{ Recoveries $(\%)$} & $\begin{array}{l}\text { Mean } \\
\text { recoveries } \\
(\%)\end{array}$ & $\begin{array}{l}\text { Srandard } \\
\text { deviation } \\
( \pm \mathrm{SD})\end{array}$ \\
\hline Malathion & 250 & 95.11 & 93.67 & 94.39 & \pm 1.02 \\
& 500 & 98.19 & 92.78 & 95.49 & \pm 3.83 \\
Diazinon & 250 & 91.77 & 84.99 & 88.38 & \pm 4.79 \\
& 500 & 94.78 & 92.34 & 93.56 & \pm 1.73 \\
Carbaryl & 250 & 87.78 & 88.00 & 87.89 & \pm 0.16 \\
& 500 & 94.45 & 94.78 & 94.62 & \pm 0.23 \\
Chlorpyrifos & 250 & 96.53 & 84.67 & 90.60 & \pm 8.39 \\
& 500 & 89.65 & 82.98 & 86.32 & \pm 4.72 \\
DDD & 250 & 91.87 & 90.34 & 91.11 & \pm 1.08 \\
& 500 & 93.00 & 91.66 & 92.33 & \pm 0.95 \\
DDT & 250 & 94.18 & 85.98 & 90.08 & \pm 5.80 \\
& 500 & 91.00 & 96.78 & 93.89 & \pm 4.09 \\
DDE & 250 & 93.74 & 87.00 & 90.37 & \pm 4.77 \\
& 500 & 85.67 & 95.89 & 90.78 & \pm 7.23 \\
\hline
\end{tabular}

liquid chromatography (HPLC). The result of the tested water samples contaminated with suspected pesticide residues is shown in Table 3. The limit of detection (LOD) for the present study is $0.3 \mu \mathrm{g} / \mathrm{L}$. The LOD of $0.01 \mu \mathrm{g} / \mathrm{L}$ was reported using HPLC fitted with Photo-Diode Array (PDA) detector by Chowdhury et al. (2012a) and Chowdhury et al. (2012b). Similarly, Hossain et al. (2014) reported the LOD of $0.1 \mu \mathrm{g} / \mathrm{L}$ using HPLC fitted with PDA detector. The LOD of $10 \mu \mathrm{g} / \mathrm{L}$ was reported by Uddin et al. (2013) using HPLC fitted with UV detector.

Among 30 water samples, malathion was detected in 7 water samples ranging from 42.58 to $922.8 \mu \mathrm{g} / \mathrm{L}$ including a tube-well water sample of Dhamrai municipality (WS28). The result is much higher than the Australian healthbased guideline value of $70 \mu \mathrm{g} / \mathrm{L}$ for malathion except for the result of municipality tube-well water sample
$(42.58 \mu \mathrm{g} / \mathrm{L})$ which was within the guideline value (NHMRC, NRMMC 2011). The concentrations are also above the Canadian maximum acceptable concentration (MAC) of $190 \mu \mathrm{g} / \mathrm{L}$ for malathion (Health Canada 2014). The result is supported by the reported value $105.2 \mu \mathrm{g} / \mathrm{L}$ by Chowdhury et al. (2012a) in a water sample from Dhamrai upazila using HPLC (Shimadzu, Japan) attached to a photo-diode array (PDA) detector. Malathion was also detected from 23.1 to $59.9 \mu \mathrm{g} / \mathrm{L}$ in lakes adjacent to agricultural fields of Savar, Bangladesh (Hossain et al. 2014), from 0.24 to $1.8 \mu \mathrm{g} / \mathrm{L}$ in southern Ontario agricultural watersheds (Braun and Frank 1980) and $0.99 \mu \mathrm{g} / \mathrm{L}$ in Ontario river basins (Frank and Logan 1988).

Diazinon was detected in only one water sample (WS-8) at a concentration of $31.5 \mu \mathrm{g} / \mathrm{L}$ which is above the Australian health-based guideline value of $4 \mu \mathrm{g} / \mathrm{L}$ (NHMRC, NRMMC 2011). The result is also above the maximum acceptable concentration (MAC) of $20 \mu \mathrm{g} / \mathrm{L}$ for diazinon in drinking water as assigned by FAO/WHO (1980) and Health Canada (2014). Chowdhury et al. (2012a) reported the presence of diazinon at the concentration of $0.9 \mu \mathrm{g} / \mathrm{L}$ in Savar but was not detected in Dhamrai during his study. Papadopoulou-Mourkidou (2002) detected up to $0.102 \mu \mathrm{g} /$ $\mathrm{L}$ diazinon in Axios Greek River. Previously diazinon was also detected in a concentration from 32.8 to $79 \mu \mathrm{g} / \mathrm{L}$ in Meharpur region (Uddin et al. 2013), at the concentration of $7.86 \mu \mathrm{g} / \mathrm{L}$ in the lake of Savar (Hossain et al. 2014), at the concentration of $0.027 \mu \mathrm{g} / \mathrm{L}$ in the paddy field of Manikganj (Bhattacharjee et al. 2012) and from less than 0.004 to $0.008 \mu \mathrm{g} / \mathrm{L}$ in stream-water samples of USA (Brigham 1994) which is much lower than the present study.

Out of thirty water samples, carbaryl was not detected at any water sample but Chowdhury et al. (2012a) detected carbaryl in water sample of Dhamrai upazila from 14.1 to $18.1 \mu \mathrm{g} / \mathrm{L}$. Carbaryl was also detected in the water samples

Table 3 Results of the detected pesticide residues in water samples showing the maximum acceptable concentration (MAC) and health-based guideline value (HBGV) Source: Health Canada (2014) for MAC and NHMRC, NRMMC (2011) for HBGV

\begin{tabular}{|c|c|c|c|c|c|c|c|c|}
\hline $\begin{array}{l}\text { Sample } \\
\text { no. }\end{array}$ & Water source & $\begin{array}{l}\text { Location } \\
\text { (union/municipality) }\end{array}$ & $\begin{array}{l}\text { Malathion } \\
(\mu \mathrm{g} / \mathrm{L})\end{array}$ & $\begin{array}{l}\text { MAC } \\
(\mu \mathrm{g} / \mathrm{L})\end{array}$ & $\begin{array}{l}\mathrm{HBGV} \\
(\mu \mathrm{g} / \mathrm{L})\end{array}$ & $\begin{array}{l}\text { Diazinon } \\
(\mu \mathrm{g} / \mathrm{L})\end{array}$ & $\begin{array}{l}\text { MAC } \\
(\mu \mathrm{g} / \mathrm{L})\end{array}$ & $\begin{array}{l}\mathrm{HBGV} \\
(\mu \mathrm{g} / \mathrm{L})\end{array}$ \\
\hline 1 & Fish pond & Dhamrai (U) & 261.06 & \multirow[t]{8}{*}{190} & \multirow[t]{8}{*}{70} & ND & \multirow[t]{8}{*}{20} & \multirow[t]{8}{*}{4} \\
\hline 2 & Fish pond & Bhararia (U) & 416.95 & & & ND & & \\
\hline 3 & Fish pond & Dhamrai (M) & 384.49 & & & ND & & \\
\hline 4 & Fish pond & Nannar (U) & 633.78 & & & ND & & \\
\hline 5 & Fish pond & Sutipara (U) & 922.8 & & & ND & & \\
\hline 8 & Fish pond & Sanora (U) & ND & & & 31.5 & & \\
\hline 24 & Cultivated land & Nannar (U) & 475.36 & & & ND & & \\
\hline 28 & Tube-well & Dhamrai (M) & 42.58 & & & ND & & \\
\hline
\end{tabular}

Limit of detection $(\mathrm{LOD})=0.3 \mu \mathrm{g} / \mathrm{L}$

$U$ union, $M$ municipality, $M A C$ maximum acceptable concentration, $H B G V$ health-based guideline value, $N D$ not detected 
of paddy field ranging from 0.055 to $0.163 \mu \mathrm{g} / \mathrm{L}$ in Rangpur (Chowdhury et al. 2012b). During the study period, chlorpyrifos pesticide was not detected. Chowdhury et al. (2012a) also reported the same result for Dhamrai but water sample of Rangpur district was contaminated with chlorpyrifos ranging from 0.477 to $1.189 \mu \mathrm{g} / \mathrm{L}$ (Chowdhury et al. 2012b). DDT, DDE and DDD were never detected in any of the water samples from Dhamrai upazila but Matin et al. (1998) reported $19.6 \mu \mathrm{g} / \mathrm{L}$ of DDT in Begumganj, Bangladesh. Chowdhury et al. (2013) also detected DDT in five several district in Bangladesh ranging from 0.133 to $8.29 \mu \mathrm{g} / \mathrm{L}$. In an average, $0.016 \mu \mathrm{g} / \mathrm{L}$ of DDT was detected in Lake Parishan, Iran (Kafilzadeh et al. 2012). Chowdhury et al. (2013) detected DDE in a water sample of Burichang contaminated with $4.06 \mu \mathrm{g} / \mathrm{L}$ which was above the health reference revel (HRL) $0.2 \mu \mathrm{g} / \mathrm{L}$ for DDE as assigned by USEPA (2008). Water sample of Lake Parishan was also contaminated with $0.055 \mu \mathrm{g} / \mathrm{L}$ of DDE (Kafilzadeh et al. 2012).

From the results of our present study, it has been revealed that organophosphorus pesticides are being used excessively in Dhamrai upazila. The presence of malathion in tube-well water is much alarming for human health inhabiting there. Malathion is an organophosphorus insecticide and acaricide used for the control of a variety of insects and mites on a wide range of agricultural and horticultural crops (FAO/WHO 1977). The rate of disappearance of malathion from soil has been reported to be 75-100\% per week (Verschueren 1983). Organophosphorus degrades quickly in between 1 and 2 weeks; as a result, pesticide cannot be identified (Lacorte et al. 1995). Since malathion, diazinon and other organophosphorus pesticides are disappeared quickly, the accurate concentration of pesticides in water is more than the detected value.

Government of Bangladesh has banned the import of POPs pesticides, but DDT is still in use for controlling mosquito vectors of malaria and dry fish insect which has been possible for trans-boundary illegal entry (ESDO 2005). The use of organochlorine insecticides (except heptachlor) for all agricultural and public health purposes was banned in Bangladesh by late 1993, although stocks could be used after that time and emergency use of limited quantities of DDT for plague control was permitted in 1994 (Matin et al. 1998). In Bangladesh at present, all Persistent Organic Pollutants (POPs) like DDT and Heptachlor import and production have been banned but at least five POPs pesticides including DDT are still in use under a different name or label (Bhuiyan et al. 2009). Islam et al. (2007) stated that DDT was allowed unrestricted use for public health purpose until it was banned in late 1993 .

Organochlorine pesticide residues and their metabolites are very stable with long half lives in the environment (ElMekkawi et al. 2009) and have a potentiality for bioaccumulation in the food chain posing a great threat to human health and the environment worldwide due to their low polarity, low aqueous solubility and high lipophilicity (Afful et al. 2010).

To protect the environment and the biodiversity from harmful effect of pesticide residues, bio-pesticides can be applied in broad scale. Bio-pesticides include microbial sourced products like bacteria, viruses, fungi and their secondary metabolites, plant and animal sourced products and pest-resistant transgenic plants (Zhu et al. 2002; Zhang and Pang 2009). Presently, there are more than 100 kinds of bio-pesticides in the world of which more than 30 kinds of bio-pesticides are commercially manufactured for pest control (Xu 2008). They will allow good control effect on pests, safe to human and other beneficial animals and causes no pollution because they have strong specificity. The pesticide residues should be monitored from different environmental samples at regular basis to assess the condition of their level and proper steps should be taken to minimize the use of pesticide and reduce the human health hazards.

\section{Conclusion}

With the increasing population followed by increasing demand of food, the use of pesticide residues has been increased a lot in the third world countries like Bangladesh. From the above results and discussions, it can be concluded that most of the farmers use organophosphorus pesticides like malathion and diazinon as these were found in several samples of Dhamrai upazila. The concentrations of the residues are out of the acceptable range for human consumption. The prolonged consumption of these pesticides through food chain can be stored in the human body and may cause severe health hazards. The presence of these suspected pesticide residues is an alarming report for the people living in this area. The farmers should be trained and campaigned for utilizing different types of alternate measures instead of pesticide to protect the crop losses due to pests attack. Frequent studies and monitoring are also needed to understand the trend of contamination. Appropriate control systems should be implemented by the authorities as soon as possible in the different parts of Bangladesh to control the misuse of pesticides and to reduce the health risk.

Acknowledgments The authors are grateful to the Director of Institute of Food and Radiation Biology (IFRB), Atomic Energy Research Establishment (AERE), Ganakbari, Savar, Dhaka to give the permission to conduct the study using the chemicals and instruments of the laboratory of Agrochemical and Environmental Research Division (AERD). 
Open Access This article is distributed under the terms of the Creative Commons Attribution 4.0 International License (http:// creativecommons.org/licenses/by/4.0/), which permits unrestricted use, distribution, and reproduction in any medium, provided you give appropriate credit to the original author(s) and the source, provide a link to the Creative Commons license, and indicate if changes were made.

\section{References}

ADB (Asian Development Bank) (2004) Case study 1: overview of small-scale freshwater aquaculture in Bangladesh. Special evaluation study on small-scale freshwater rural aquaculture development for poverty reduction. Sst: Reg 2004-07

Afful S, Anim AK, Serfor-Armah Y (2010) Spectrum of organochlorine pesticide residues in fish samples from the Densu Basin. Res J Environ Earth Sci 2(3):133-138

Ara AG, Haque W, Hasanuzzaman M (2014) Detection of Organochlorine and organophosphorus pesticides residues in water samples of Taragong thana in Rangpur district in Bangladesh. Res J Environ Earth Sci 6(2):85-89

Badruddin M (2004) Pesticide \& its management in Bangladesh. Annex II of the Bangladesh inception report

Bagchi S, Azad AK, Chowdhury MAZ, Uddin MA, Al-Reza SM, Rahman MA (2009) Quantitative analysis of pesticide residues in some pond water samples of Bangladesh. Asian J Water Environ Pollut 6(4):27-30

Banglapedia (2015) National encyclopedia of Bangladesh: Dhamrai upazila. http://en.banglapedia.org/index.php?title=Dhamrai Upazila. Accessed on 27 Aug 2016

BBS (2013) Statistical yearbook of Bangladesh 2012. Bangladesh bureau of statistics, statistics and informatics division (SID). Ministry of planning, Government of the People's Republic of Bangladesh. Dhaka, Bangladesh, 32nd edition. www.bbs.gov.bd

BBS (2014) Statistical pocketbook of Bangladesh-2013. Bangladesh bureau of statistics, statistics and informatics division (SID). Ministry of planning, Government of the People's Republic of Bangladesh. Dhaka, Bangladesh. www.bbs.gov.bd

Bhattacharjee S, Fakhruddin ANM, Chowdhury MAZ, Rahman MA, Alam MK (2012) Monitoring of selected pesticides residue levels in water samples of cultivated lands and removal of cypermethrin and chlorpyrifos residues from water using rice bran. Bull Environ Contam Toxicol 89(2):348-353

Bhuiyan MNH, Bhuiyan HR, Nath KK, Ahmed K, Hassan MT, Bhuiyan MNI (2009) Organochlorine insecticides (DDT and Heptachlor) in dry fish available in Bangladesh: seasonal trends and species variability. J Chil Chem Soc 54(3):278-281

Braun HE, Frank R (1980) Organochlorine and organophosphorus insecticides: their use in eleven agricultural watersheds and their loss to stream waters in southern Ontario, Canada, 1975-1977. Sci Total Environ 15:169

Brigham ME (1994) Pesticides detected in surface waters and fish of the Red River of the North Drainage Basin. In: North Dakota water quality symposium proceedings, March 30-31, 1994, Fargo, North Dakota State University extension service, pp 256-269

Chen JP, Lin G, Zhou BS (2004) Correlation between pesticides exposure and mortality of breast cancer. China Public Health 20:289-290

Chowdhury MTI, Razzaque MA, Khan MSI (2011) Chlorinated pesticide residue status in tomato, potato and carrot. J Exp Sci 2(1): $1-5$
Chowdhury MAZ, Banik S, Uddin B, Moniruzzaman M, Karim N, Gan SH (2012a) Organophosphorus and carbamate pesticide residues detected in water samples collected from paddy and vegetable fields of the Savar and Dhamrai upazilas in Bangladesh. Int J Environ Res Public Health 9:3318-3329. doi:10.3390/ijerph9093318

Chowdhury MAZ, Jahan SA, Islam MN, Moniruzzaman M, Alam MK et al (2012b) Occurrence of organophosphorus and carbamate pesticide residues in surface water samples from the Rangpur district of Bangladesh. Bull Environ Contam Toxicol 89:202-207. doi:10.1007/s00128-012-0641-8

Chowdhury MAZ, Islam MN, Moniruzzaman M, Gan SH, Alam MK (2013) Organochlorine insecticide residues are found in surface, irrigated water samples from several districts in Bangladesh. Bull Environ Contam Toxicol 90:149-154. doi:10.1007/s00128012-0897-z

DFG (Deutsche Forschungsgemeinschaft) (1987) Manual of pesticide residue analysis. Wiley $\mathrm{VCH}$ Verlagsgesellschaft $\mathrm{mbH} \mathrm{1:324}$

El-Mekkawi H, Diab M, Zaki M, Hassan A (2009) Determination of chlorinated organic pesticide residues in water, sediments and fish from private fish farms at Abbassa and Sahl Al-Husainia, Sharkia Governorate. Aus J Basic Appl Sci 3(4):4376-4383

ESDO (Environment and Social Development Organization) (2005) Country situation report on persistent organic pollutants in Bangladesh. In: International POPs elimination project, fostering active and efficient civil society participation in preparation for implementation of the Stockholm convention, Bangladesh

FAO/WHO (1977) Data sheet on pesticides, No. 29-malathion. World Health Organization, Geneva

FAO/WHO (1980) Pesticide residues in food: 1979 evaluations. FAO plant production and protection paper 20 Sup, Food and Agriculture Organization of the United Nations, Rome. http:// www.hc-sc.gc.ca/ewh-semt/pubs/water-eau/diazinon/index-eng. php

Frank R, Logan L (1988) Pesticide and industrial chemical residues at the mouth of the grand, Saugeen and Thames rivers, Ontario, Canada, 1981-85. Arch Environ Contam Toxicol 17:741

GHS (2009) Globally harmonized system of classification and labeling of chemicals (GHS), 3rd revised edition. United Nations, New York and Geneva. http://www.unece.org/trans/ danger/publi/ghs/ghs_rev03/03files_e.html

GoB (Government of the People's Republic of Bangladesh), MoEF (Ministry of Environment and Forests) (2005) Pesticide inventory of Bangladesh 2005. Field data collection and preparation of inventories on use/stock/production/sources of POPs pesticide in Bangladesh, MoEF

Gu XJ, Tian SF (2005) Pesticides and cancer. World Sci-tech R \& D 27(2):47-52

Health Canada (2014) Guidelines for Canadian drinking water quality-summary table. Water and air quality bureau, healthy environments and consumer safety branch, Health Canada, Ottawa, Ontario

Hossain MS, Chowdhury MAZ, Pramanik MK, Rahman MA, Fakhruddin ANM, Alam MK (2014) Determination of selected pesticides in water samples adjacent to agricultural fields and removal of organophosphorus insecticide chlorpyrifos using soil bacterial isolates. Appl Water Sci. doi:10.1007/s13201-0140178-6

Hossain MS, Fakhruddin ANM, Chowdhury MAZ, Rahman MA, Alam MK (2015) Health risk assessment of selected pesticide residues in locally produced vegetables of Bangladesh. Int Food Res J 22(1):110-115

Islam MN, Haque SM, Chowdhury MAZ, Rahman MA, Fardous Z (2007) Monitoring of organochlorine pesticide residues in surface water samples of the agricultural field of Bangladesh. J Subtrop Agric Res Dev 5(5):357-360 
Kafilzadeh F, Shiva AH, Malekpour R, Azad HN (2012) Determination of organochlorine pesticide residues in water, sediments and fish from lake Parishan, Iran. World J Fish Mar Sci 4(2):150-154. doi:10.5829/idosi.wjfms.2012.04.02.56399

Lacorte S, Lartiges SB, Garrigues P, Barcelo D (1995) Degradation of organophosphorus pesticides and their transformation products in estuarine waters. Environ Sci Technol 29(2):431-438. doi:10. 1021/es00002a020

Matin MA, Malek MA, Amin MR, Rahman S, Khatoon J, Rahaman M, Aminuddin M, Mian AJ (1998) Organochlorine insecticide residues in surface and underground water from different regions of Bangladesh. Agric Ecosyst Environ 69:11-15

MoF (Ministry of Finance) (2015) Bangladesh economic review (BER)/Bangladesh orthonoitik somikkha (in Bengali) 2015, economic adviser's wing, finance division, ministry of finance, Government of the People's Republic of Bangladesh. www.mof. gov.bd

NHMRC (National Health and Medical Research Council), NRMMC (National Resource Management Ministerial Council) (2011) Australian drinking water guidelines paper 6, national water quality management strategy. Commonwealth of Australia, Canberra. http://www.nhmrc.gov.au

OLeary ES, Vena JE, Freudenheim JL, Brasure J (2004) Pesticide exposure and risk of breast cancer: a nested case-control study of residentially stable women living on Long Island. Environ Res 94(2):134-144

Papadopoulou-Mourkidou E (2002) Quality of surface waters of Macedonia- Thrace, Northern Greece, quality control program, final report (in Greek). Ministry of agriculture, Thessaloniki

Pimentel D (1997) Techniques for reducing pesticide use: Environmental and economic benefits. John Wiley and Sons, Chichester

Pimentel D (2009a) Pesticides and pest control. In: Peshin R, Dhawan AK (eds) Integrated pest management: innovation-development process, vol 1. Springer, Netherlands, pp 83-87

Pimentel D (2009b) Environmental and economic costs of the application of pesticides primarily in the United States. In: Peshin R, Dhawan AK (eds) Integrated pest management: innovation-development process, vol 1. Springer, Netherlands, pp 88-111

Rahman MM (2000) Pestcides: their uses and problems in context of Bangladesh. In: proceedings of the national workshop on conventional and nuclear technique for pesticide residues studies in food and environment at IFRB, Savar, Bangladesh, pp 1-25

Rahman MM (2004) Uses of persistent organic pollutants (POPs) in Bangladesh. In: Paper presented at the inception workshop of the project Bangladesh: preparation of POPs national implementation plan under Stockholm convention (POP NIP), department of environment, held at Hotel Sonargaon, Bangladesh

Recio R, Robbins WA, Borja-Aburto V, Moran-Martinez J, Froines JR, Hernandez RM, Cebrian ME (2001) Organophosphorus pesticide exposure increases the frequency of sperm sex null aneuploidy. Environ Health Persp 109(12):1237

Saldana TM, Basso O, Baird DD, Hoppin JA, Weinberg CR, Blair A, Sandler DP (2009) Pesticide exposure and hypertensive disorders during pregnancy. Environ Health Persp 117(9):1393-1396

Uddin MA, Saha M, Chowdhury MAZ, Rahman MA (2013) Pesticide residues in some selected pond water samples of Meherpur region of Bangladesh. J Asiat Soc Bangladesh Sci 39(1):77-82

USEPA (United States Environmental Protection Agency) (2008) Health effects support document for 1,1-Dichloro-2,2-bis(pchlorophenyl)ethylene (DDE). In: US environmental protection agency office of water (4304T) health and ecological criteria division Washington, DC 20460. EPA-822-R-08-003. www.epa. gov/safewater/ccl/pdf/DDE.pdf

Van de Zande JC, Porskamp HAJ, Michielsen JMGP, Holterman HJ, Huijsmans JMF (2000) Classification of spray applications for drift ability, to protect surface water. Asp Appl Biol 57:57-64

Van Wijngaarden RPA, Brock TCM, Van den Brink PJ (2005) Threshold levels for effects of insecticides in freshwater ecosystems: a review. Ecotoxicology 14(3):355-380

Verschuerenn K (1983) Handbook of environmental data on organic chemicals, 2nd edn. Van Nostrand Reinhold Co., New York

WHO (2010) WHO Recommended classification of pesticides by hazard and guidelines to classification 2009. Non serial Publication Series, pp 1-78

WHO/NHMRC (2006) International meeting on the management of water quality in rural and remote communities, Alice Springs, Australia, 19-22 July 2005. WHO/SDE/WSH/06.3

World Resources Institute (2003) Earth trends. Country profiles, Bangladesh. http://earthtrends.wri.org/pdf_library/country_ profiles/Agr_cou_050.pdf

$\mathrm{Xu}$ YZ (2008) The application of biological pesticides and industrial development measures. Chin Agric Sci Bull 24(8):402-404

Zhang WJ, Pang Y (2009) Impact of IPM and transgenics in the Chinese agriculture. In: Peshin R, Dhawan AK (eds) Integrated pest management: dissemination and impact. Springer, Berlin, pp 525-553

Zhu CX, Bai XS, Zhang M (2002) The status quo of development and perspective of biopesticides. Shanghai Environ Sci 21(11):654-659 